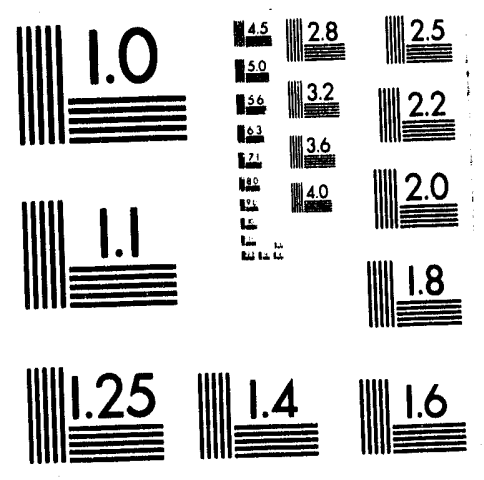



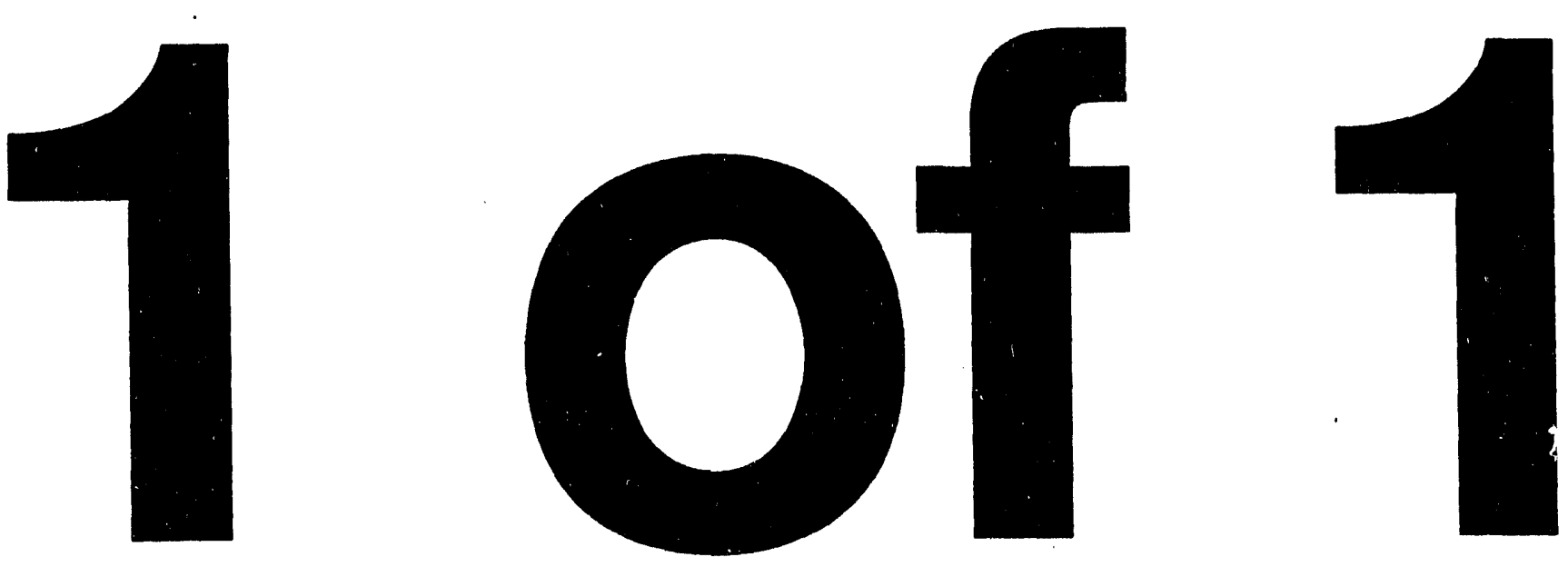


\section{NITRIC-PHOSPHORIC ACID TREATMENT OF TRU WASTES} (U)

by

J. R. Smith

Westinghouse Savannah River Company

Savannah River Site

Aiken, South Carolina 29808

R. A. Pierco

E. F. Sturcken

This paper was prepared in connection with work done under the above contract number with the U. S.

Department of Energy. By acceptance of this paper, the publisher and/or recipient acknowledges the U. S. Government's right to retain a nonexclusive, royalty-free license in and to any copyright covering this paper, along with the right to reproduce and to authorize others to reproduce all or part of the copyrighted paper. 


\section{DISCLAIMER}

This report was prepared as an account of work sponsored by an agency of the United States Government. Neither the United States Government nor any agency thereof nor any of their employees, makes any warranty, express or implied, or assumes any legal liability or responsibility for the accuracy. completeness, or usefulness of any information, apparatus, product, or process disclosed, or represents that its use would not infringe privately owned rights. Reference herein to any specific commercial product, process, or service by trade name, trademark, manufacturer, or otherwise does not necessarily constitute or imply its endorsement, recommendation, or favoring by the United States Government or any agency thereof. The views and opinions of authors expressed herein do not necessarily state or reflect those of the United States Government or any agency thereof.

This report has been reproduced directly from the best available copy.

Available to DOE and DOE contractors from the Office of Scientific and Technical Information, P. O. Box 62, Oak Ridge, TN 37831: prices available from (615) $576-8401$

Available to the public from the National Technical Information Service, U. S. Department of Commerce, 5285 Port Royal Rd., Spriagfield, VA 22161 
WSRC-RP-93-1304

Nitric-Phosphoric Acid Treatment of TRU Wastes (U)

J.R. Smith, R.A. Pierce, and E.F. Sturcken

Westinghouse Savannah River Company Savannah River Site

Aiken, SC 29808 
WSRC-RP-93-1304

$\mathrm{Pg} 1$ of 15

Nitric-Phosphoric Acid Treatment of TRU Wastes (U)
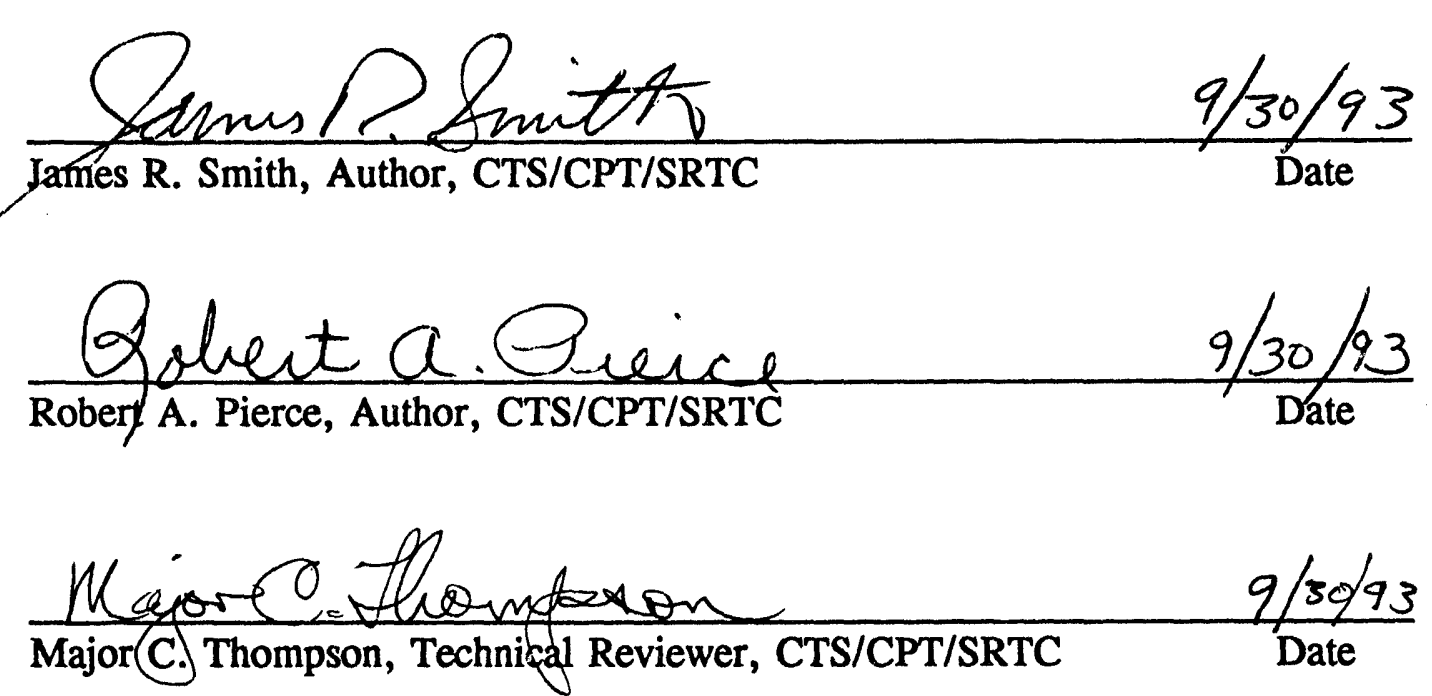

September 30, 1993

Westinghouse Savannah River Company Savannah River Site

Aiken, SC 29808 
WSRC-RP-93-1304

$\mathrm{Pg} 2$ of 15

\section{CONTENTS}

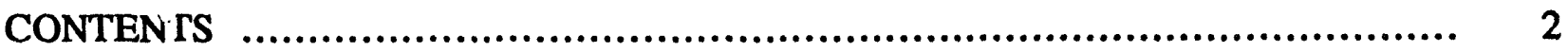

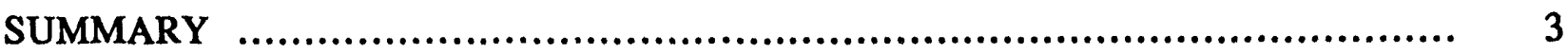

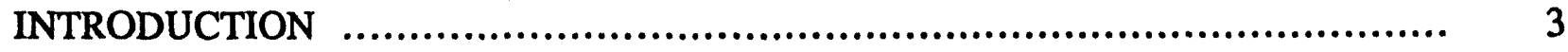

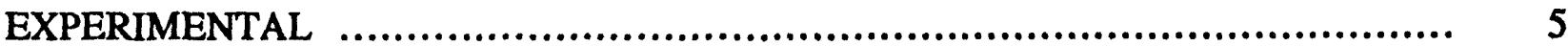

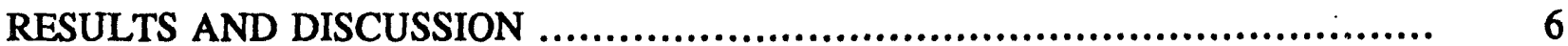

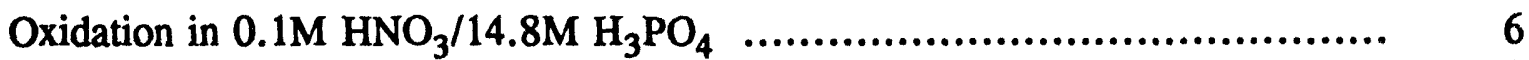

Oxidation Under Microwave Digestion Conditions .............................. 8

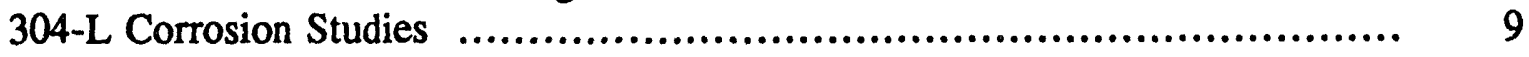

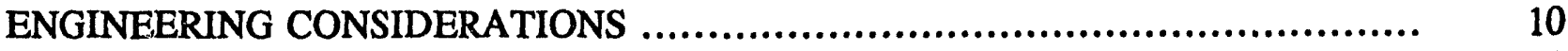

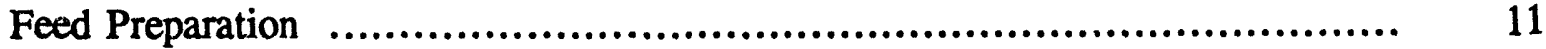

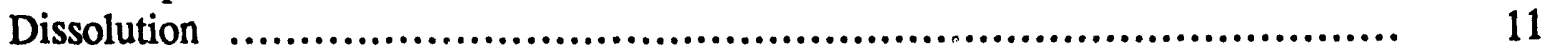

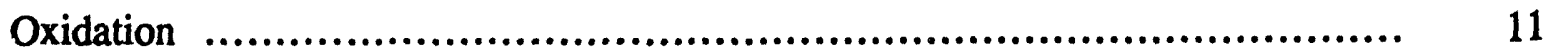

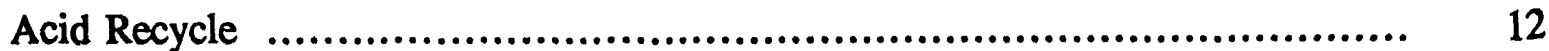

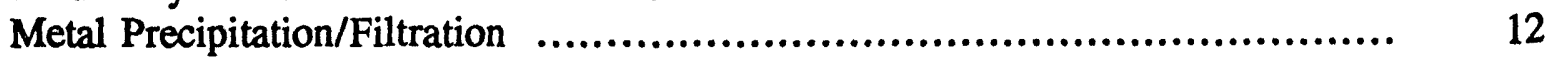

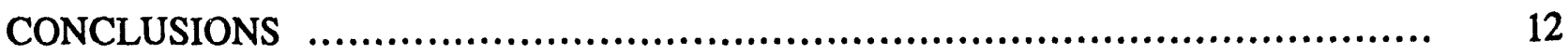

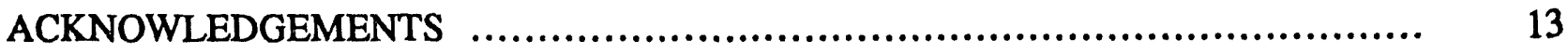

TABLES

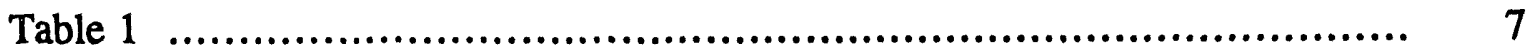

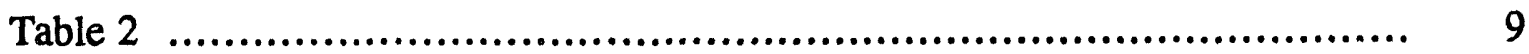

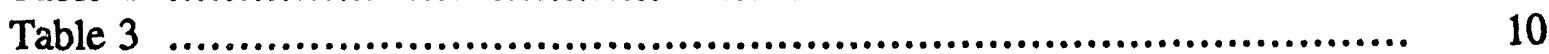

FIGURES

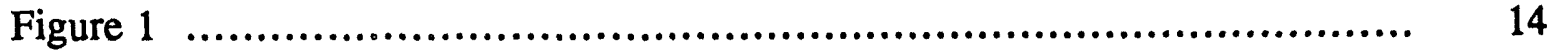

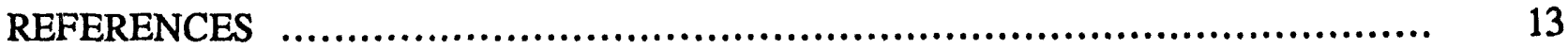


WSRC-RP-93-1304

Pg 3 of 15

\author{
Nitric-Phosphoric Acid Treatment of TRU Wastes (U) \\ by J. R. Smith, R. A. Pierce, and E. F. Sturcken \\ Westinghouse Savannah River Company \\ Savannah River Site \\ Aiken, SC 29808
}

\title{
SUMMARY
}

A general process is being developed for the treatment of solid TRU and hazardous organic waste. Experimental data indicates that $100 \mathrm{lb} / \mathrm{hr}$ of aliphatic organic (plastics) and 1000 $\mathrm{lb} / \mathrm{hr}$ of non-aliphatic organic compounds can be quantitatively oxidized in a 1000 gallon reaction vessel. The process uses dilute nitric acid in a concentrated phosphoric acid media as the main oxidant for the organic compounds. Phosphoric acid allows oxidation at temperatures up to $200^{\circ} \mathrm{C}$ and is relatively non-corrosive on 304-L stainless steel, especially at room temperature.

Many organic materials have been completely oxidized to $\mathrm{CO}_{2}, \mathrm{CO}$, and inorganic acids in a $0.1 \mathrm{M} \mathrm{HNO}_{3} / 14.8 \mathrm{M} \mathrm{H}_{3} \mathrm{PO}_{4}$ solution. Addition of $0.001 \mathrm{M} \mathrm{Pd}^{+2}$ reduces the $\mathrm{CO}$ to near $1 \%$ of the released carbon gases. To accomplish complete oxidation the solution temperature must be maintained above $130-150^{\circ} \mathrm{C}$. Organic materials quantitatively destroyed include neoprene, cellulose, EDTA, TBP, tartaric acid, and nitromethane. The oxidation is usually complete in a few hours for soluble organic materials. The oxidation rate for non-aliphatic organic solids is moderately fast and surface area dependent. Polyethylene is quantitatively oxidized in $1.0 \mathrm{M}$ $\mathrm{HNO}_{3} / 13.8 \mathrm{M} \mathrm{H}_{3} \mathrm{PO}_{4}$ solution while contained in pressure vessels heated with microwave energy. This is probably due to the high concentrations of $\mathrm{NO}_{2} \cdot$ obtained in the reaction environment.

\section{INTRODUCTION}

The development of a general process for the destructive oxidation of pure organic compounds could have many applications for environmental cleanup. A liquid phase oxidation process shouldn't produce any ash, making the system more environmentally contained. A simple process that uses oxygen from air or another readily available cheap oxidant as the net oxidizer would be relatively inexpensive per unit of waste consumed. This work represents studies to develop such a process. Nitric acid is used as a catalyst and oxidant since it can be regenerated by air in an acid recovery system and to some extent in the reaction solution.

Liquid phase oxidation of organic molecules should be easier than gas phase oxidation at a given temperature ${ }^{1}$. This is due to the ability to produce high concentrations of the reactants 
and to the lessening of termination since radicals have a harder time diffusing to the walls. Direct oxidation of most organic compounds by $\mathrm{HNO}_{3}$, nitric acid, is energetically favorable but very slow due to its inability to break the carbon-hydrogen bond ${ }^{1,2}$. The following heats of reaction, $\Delta \mathrm{H}$, values are in $\mathrm{kcal} / \mathrm{mole}^{1,2,3}$.

$$
\begin{array}{ll}
\mathrm{RCH}_{3}+\mathrm{HNO}_{3} \longrightarrow \mathrm{RCH}_{2} \mathrm{OH}+\mathrm{HNO}_{2} & \Delta \mathrm{H} \approx-25 \\
\mathrm{RCH}_{3}+\mathrm{HNO}_{3} \longrightarrow \mathrm{RCH}_{2} \cdot+\mathrm{H}_{2} \mathrm{O}+\mathrm{NO}_{2} \cdot & \Delta \mathrm{H} \approx 35 \\
\mathrm{RCH}_{3}+\mathrm{HNO}_{2} \longrightarrow \mathrm{RCH}_{2} \cdot+\mathrm{H}_{2} \mathrm{O}+\mathrm{NO} \cdot & \Delta \mathrm{H} \approx 28
\end{array}
$$

$R$ denotes an organic group not affecting the $\Delta H$ for the shown reaction. The oxidation of organic compounds is usually initiated by the production of organic radicals generated by dissolved $\mathrm{NO}_{2} \cdot$ and $\mathrm{NO} \cdot$ in solution $\left(\mathrm{NO}_{2}\right.$ and $\mathrm{NO}$ are radicals and will be noted as such in this document). For many types of organic compounds the attack by $\mathrm{NO}_{2} \cdot$ can be first order.

$$
\begin{array}{ll}
\mathrm{CH}_{3}(\mathrm{OH}) \mathrm{CH}_{2}+\mathrm{NO}_{2} \cdot \longrightarrow \mathrm{CH}_{3}(\mathrm{OH}) \mathrm{CH} \cdot+\mathrm{HNO}_{2} & \Delta \mathrm{H} \approx 0 \\
\mathrm{CH}_{3} \mathrm{CHO}+\mathrm{NO}_{2} \cdot \longrightarrow \mathrm{CH}_{3}(\mathrm{O}) \mathrm{C} \cdot+\mathrm{HNO}_{2} & \Delta \mathrm{H}=-7
\end{array}
$$

For aliphatic compounds high concentrations of $\mathrm{NO}_{2} \cdot$ and $\mathrm{NO} \cdot$ are needed.

$$
\begin{array}{ll}
\mathrm{RCH}_{3}+\mathrm{H}_{2} \mathrm{O}+3 \mathrm{NO}_{2} \cdot \longrightarrow \mathrm{RCH}_{2}+2 \mathrm{HNO}_{2}+\mathrm{HNO}_{3} & \Delta \mathrm{H} \approx-15 \\
\mathrm{RCH}_{3}+\mathrm{H}_{2} \mathrm{O}+2 \mathrm{NO}_{2} \cdot+\mathrm{NO} \cdot \longrightarrow \mathrm{RCH}_{2}+3 \mathrm{HNO}_{2} & \Delta \mathrm{H} \approx-8
\end{array}
$$

A typical aliphatic carbon-hydrogen bond strength of $99 \mathrm{kcal} / \mathrm{mole}$ was used in the calculations ${ }^{2}$. The organic radicals are then oxidized by nitric and nitrous acids or nitrated by $\mathrm{NO}_{2}$.

$$
\begin{array}{lr}
\mathrm{RCH}_{2}+\mathrm{HNO}_{3} \rightarrow \mathrm{RCH}_{2} \mathrm{OH}+\mathrm{NO}_{2} \cdot & \Delta \mathrm{H} \approx-35 \\
\mathrm{RCH}_{2} \cdot+\mathrm{HNO}_{2} \rightarrow \mathrm{RCH}_{2} \mathrm{OH}+\mathrm{NO}^{\cdot} & \Delta \mathrm{H} \approx-42 \\
\mathrm{RCH}_{2}+\mathrm{NO}_{2} \cdot \rightarrow \mathrm{RCH}_{2} \mathrm{NO}_{2} & \Delta \mathrm{H} \approx-52
\end{array}
$$

Hydrogen-carbon bonds on carbon atoms which are also bonded to oxygen are weakened, allowing much quicker hydrogen abstraction and further oxidation. As the organic molecules gain more oxygen atoms the organic molecules become increasingly more soluble in the oxidation solution. Once in solution the molecules are quickly oxidized to $\mathrm{CO}_{2}, \mathrm{CO}$, and water. If the original organic compound contains chlorine then $\mathrm{HCl}$ (hydrochloric acid) will also be formed.

Microwave dissolution techniques are fairly well developed procedures for the dissolution of organic samples as a part of analytical sample preparation. These techniques use mineral acids and oxidants, such as hydrogen peroxide or nitric acid, at elevated pressure and temperature to digest organic samples. The role of the microwave energy, other than heating, is probably small since it is of insufficient energy to cause bond breakage. Reactions (1) and (2) are very likely the initiating oxidation steps when the oxidant is $\mathrm{HNO}_{3}$ since under microwave digestion conditions the $\mathrm{NO} \cdot$ and $\mathrm{NO}_{2} \cdot$ arc trapped and build up to high concentrations in the pressure vessel. 
WSRC-RP-93-1304

$\mathrm{Pg} 5$ of 15

\section{EXPERIMENTAL}

Weight measurements were taken using a Sartorius (Handy) balance. All chemicals used were of at least Reagent grade quality meeting ACS specifications except for the cellulose (Whatman 40 ashless filter paper) and neoprene (glovebox glove made by Siebe North, Inc., Charleston SC). Gas samples were analyzed on a Varian 3400 GC using Molecular Sieve-13X and Chromosorb 106 columns.

The data collected was generated from two similar but different oxidation systems. The first used a peristaltic pump to circulate air through a closed system starting with (and continuing in order) a three liter reaction vessel containing a liter of reactant solution, an ice trap, a 26.6 liter polypropylene bottle, a $30 \mathrm{ml}$ gas sample vessel, and then re-entering the peristaltic pump 4 . The system was connected to an inverted burette, in acidic solution, used to measure changes in the gas volume of the system. The total gas volume of the system was $29.0 \pm 0.2$ liters. The air entered the reaction solution through a three inch diameter medium glass frit plate generating very small bubbles in the solution. The air circulation rate for this system was maintained at 500 $\mathrm{ml} / \mathrm{minute}$. The all-glass three liter reaction vessel set in a heating mantle and had four ground glass openings which provided access for a thermometer, an air cooled condenser (air outlet), air sparge inlet, and sample introduction-holder port. Gas samples were taken at the beginning, end, and during the oxidation reaction. Carbon balance results gave a combined error of $\pm 3 \%$.

The second system was of a flow-through design 5 . A peristaltic pump was used to push air through the reaction system. The incoming air was stripped of $\mathrm{CO}_{2}$ using Ascarite-II (Thomas Scientific). The air was delivered to the reaction vessel at $100 \mathrm{ml} / \mathrm{minute}$. The reaction vessel was the same as described above except that a smaller glass frit sparger was used. The gas stream leaving the reaction vessel was scrubbed of $\mathrm{NO}_{2} \cdot$ by a $C .5 \mathrm{M}$ sulfamic acid solution. The products of the $\mathrm{NO}_{2} \cdot$ reaction with the sulfamic acid was nitric acid (stays in solution) and $\mathrm{N}_{2}$ gas. The gas stream then entered approximately 100 grams of Ascarite-II in a polypropylene bottle. Weighing the bottle before and after the reaction determined the weight of $\mathrm{CO}_{2}$ produced from the oxidation. The gas stream then entered a column of Pd metal on a Kieselguhr support maintained above $140^{\circ} \mathrm{C}$. The $\mathrm{Pd} / \mathrm{Kieselguhr}$ catalyzes the air oxidation of any $\mathrm{CO}$ in the gas stream to $\mathrm{CO}_{2}$. The generated $\mathrm{CO}_{2}$ is then absorbed and weighed on a second bottle of AscariteII. Calibration of this system for the absorption of $\mathrm{CO}$ and $\mathrm{CO}_{2}$ was accomplished by adding a weighed amount of dried sodium oxalate to concentrated sulfuric or phosphoric acid. In the absence of oxidizing compounds an equal molar amount of $\mathrm{CO}$ and $\mathrm{CO}_{2}$ is formed. Carbon balances from the calibration determined a combined accuracy of $\pm 2 \%$.

For the microwave digestion experiments sample weight measurements were taken using a Mettler AC 100 balance. Other weight measurements were taken using a Sartorius (Handy) balance. Polyethylene, polypropylene, and high-density polyethylene samples were taken from Nalgene bottles. Other samples include, polyvinylchloride, Tygon ${ }^{\mathrm{TM}}$, and a styrenedivinylbenzene resin (Rohm and Haas IRN-150). The microwave pressure vessel dissolution units were manufactured by Floyd, Inc. (Lake Wylie, South Carolina). The first experiments focused on the feasibility of plastic dissolution in concentrated nitric acid and were judged solely 
WSRC-RP-93-1304

Pg 6 of 15

on a success or failure basis. Later experiments which aimed at providing a carbon balance used the second oxidation system described earlier to collect data.

The 304-L corrosion study data was acquired using reagent grade chemicals and two 304L stainless steel coupons labeled (stamped) \#26 and \#27. A Sartorius (Handy) balance was used for weight measurements. Precision calipers were used for dimension measurements.

\section{RESULTS AND DISCUSSION}

\section{Oxidation in $0.1 \mathrm{M} \mathrm{HNO} 3 / 14.8 \mathrm{M} \mathrm{H}_{3} \mathrm{PO}_{4}$}

The onset of oxidation for the soluble organic compounds was about $120^{\circ} \mathrm{C}$. Gram quantities of organic material were oxidized per run. At $140^{\circ} \mathrm{C}$ the oxidation was complete in less than 15 minutes $\left(\mathrm{NO}_{2} \cdot\right.$ stopped being released from the solution). The results of the carbon balance studies are tabulated in Table 1. Complete oxidation, within experimental error, was obtained for the compounds listed (with the exception of tartaric acid) for at least one of the runs. Tartaric acid should also be completely oxidizable. The purpose for the oxidation of tartaric acid was to determine the fraction of $\mathrm{CO}$ released. The results show that a more highly oxidized compound, such as tartaric acid, releases a smaller fraction of CO. The production of $\mathrm{CO}$ was very pronounced for TBP (tributylphosphate) and nitromethane. The result for nitromethane is not surprising since it should be quickly hydrolysed to formic acid in a strong mineral acid at these temperatures ${ }^{6}$.

$$
\begin{array}{ll}
\mathrm{CH}_{3} \mathrm{NO}_{2}+\mathrm{H}_{2} \mathrm{O}+\mathrm{H}_{3} \mathrm{PO}_{4} \rightarrow \mathrm{HCO}_{2} \mathrm{H}+\mathrm{H}_{2} \mathrm{NOH} \cdot \mathrm{H}_{3} \mathrm{PO}_{4} & \Delta \mathrm{H} \approx-44 \\
\mathrm{H}_{2} \mathrm{NOH} \cdot \mathrm{H}_{3} \mathrm{PO}_{4}+\mathrm{HNO}_{2} \rightarrow \mathrm{N}_{2} \mathrm{O}+2 \mathrm{H}_{2} \mathrm{O}+\mathrm{H}_{3} \mathrm{PO}_{4} & \Delta \mathrm{H}=-66
\end{array}
$$

Dehydration of formic acid to $\mathrm{CO}$ and water is sightly endothermic $(4 \mathrm{kcal} / \mathrm{mole})^{2}$ but probably quick in $14.8 \mathrm{M} \mathrm{H}_{3} \mathrm{PO}_{4}$ which is a strong dehydrating agent. The strong dehydrating ability of the reaction solution is probably aiding in the decomposition of the organic oxidation products. Cellulose is rapidly carbonized at around $140^{\circ} \mathrm{C}$ to form carbon and water.

$$
\begin{aligned}
& \mathrm{RCH}(\mathrm{OH}) \mathrm{CO}_{2} \mathrm{H} \rightarrow \mathrm{H}_{2} \mathrm{O}+\mathrm{CO}+\mathrm{RCHO} \\
& \mathrm{C}_{6} \mathrm{H}_{10} \mathrm{O}_{5} \text { (cellulose) } \rightarrow 6 \mathrm{C}+5 \mathrm{H}_{2} \mathrm{O}
\end{aligned}
$$

The carbon formed is easily attacked by the nitric acid. It is possible that the relative production of $\mathrm{CO}$ and $\mathrm{CO}_{2}$ is determined by competing mechanisms; the $\mathrm{CO}$ by a dehydration mechanism and the $\mathrm{CO}_{2}$ produced by oxidation with $\mathrm{HNO}_{3}$ and $\mathrm{NO}_{2}$.

$$
\begin{array}{ll}
\mathrm{CH}_{3} \mathrm{CHO}+\mathrm{NO}_{2} \cdot \longrightarrow \mathrm{CH}_{3}(\mathrm{O}) \mathrm{C} \cdot+\mathrm{HNO}_{2} & \Delta \mathrm{H}=-7 \\
\mathrm{CH}_{3}(\mathrm{O}) \mathrm{C} \cdot+\mathrm{HNO}_{3} \longrightarrow \mathrm{CH}_{3} \cdot+\mathrm{CO}_{2}+\mathrm{HNO}_{2} & \Delta \mathrm{H}=4
\end{array}
$$

The slightly endothermic $\Delta \mathrm{H}$ for this last reaction shows how dehydration to produce $\mathrm{CO}$ can compete with oxidation to produce $\mathrm{CO}_{2}$. 
WSRC-RP-93-1304

$\operatorname{Pg} 7$ of 15

Table 1. Carbon Balance for Oxidation of Various Organic Compounds in a $0.05-0.1 \mathrm{M} \mathrm{HNO}_{3} / 14.8 \mathrm{M} \mathrm{H}_{3} \mathrm{PO}_{4}$ Solution, $120-160^{\circ} \mathrm{C}$.

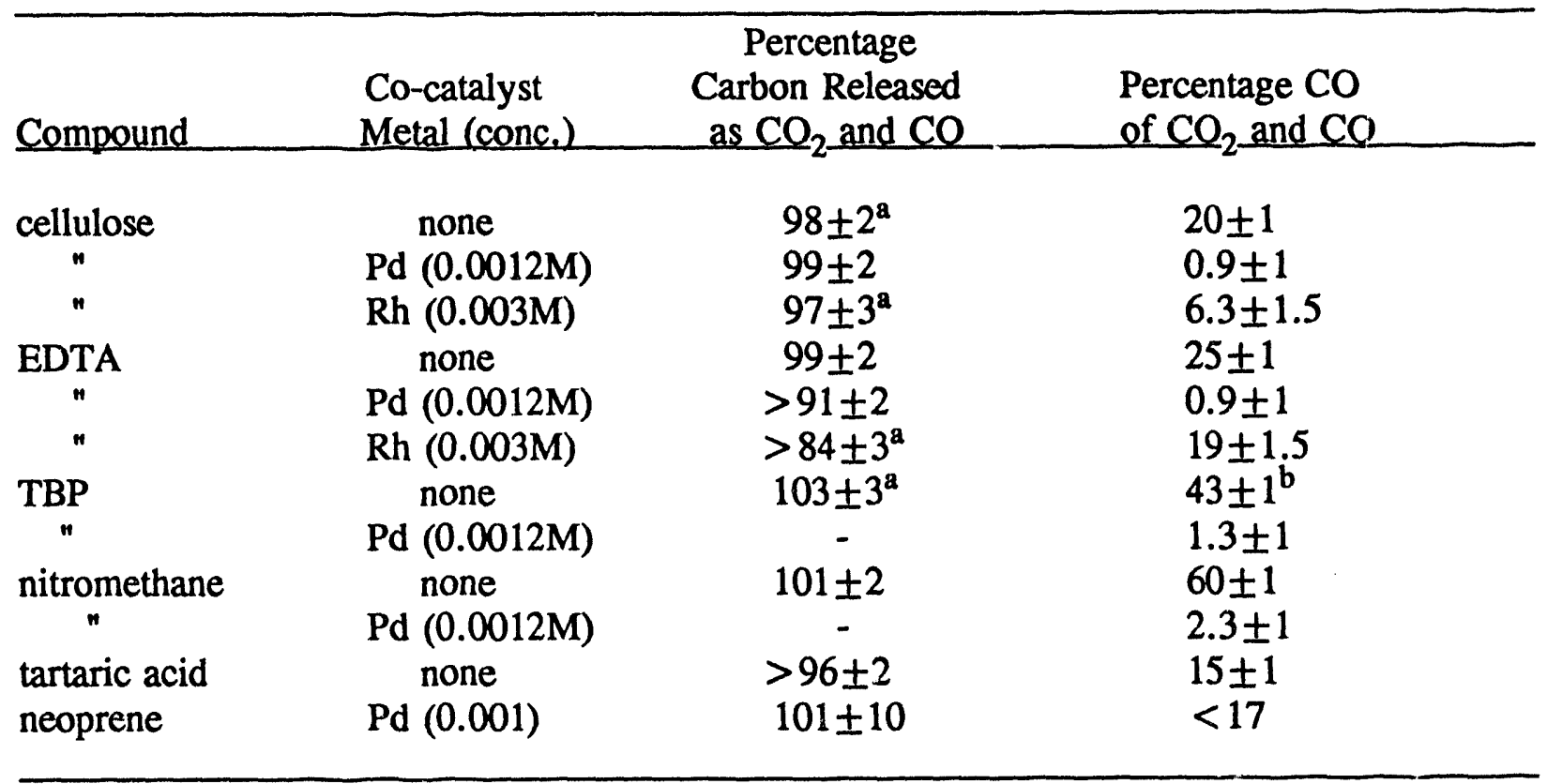

a $\mathrm{GC}$ analysis observed no $\mathrm{H}_{2}$, methane, or ethane.

b Determined from butanol (a hydrolysis product of TBP)

Carbon-nitrogen bonds are relatively weak $(\sim 75 \mathrm{kcal} / \mathrm{mole})^{1}$ so complete oxidation of EDTA (ethylene-diamine-tetraacetic acid) was not surprising. Oxidation of TBP was performed to test the ability to destroy nearly aliphatic compounds. Butanol, a hydrolysis product of TBP, resembles an aliphatic compound except for the alcohol group. The weakening of the adjacent carbon-hydrogen bonds by this lone oxygen seems to be sufficient to start the chain oxidation process. Oxidation of compounds of this type have been said to act like a candle that has been lit on one end ${ }^{1}$. The carbon atoms are oxidized in order down the chain.

The surface oxidation of neoprene (poly [2-chloro-1,3-butadiene]) was found to be even, allowing measurement of the surface area and weight loss during its destruction. The oxidation rate at varying temperatures has been measured for this compound, Figure 1 . The activation energy, $E_{a}$, was determined to be $22.9 \mathrm{kcal} / \mathrm{mole}$ with a frequency factor, $\mathrm{A}$, of $7.68 \mathrm{E} 11 \mathrm{~s}^{-1}$. The release of chloride during the oxidation had no observable effect at the low concentration, up to $0.1 \mathrm{M}$, formed by the destruction of the neoprene. Oxidation of neoprene is relatively rapid due to carbon-carbon double bond weakening of carbon-hydrogen bonds in $\alpha$ positions relative to the double bond ${ }^{1}$.

The oxidation of aliphatic compounds such as polyethylene, PVC (polyvinylchloride), and $\mathrm{n}$-dodecane was found to be unmeasureably slow in this reaction solution below $180^{\circ} \mathrm{C}$. In an air sparged system the concentration of $\mathrm{NO} \cdot$ and $\mathrm{NO}_{2} \cdot$ should be too low for reactions (1) and (2) to have any appreciable effect. It should be possible though under the right reaction 
WSRC-RP-93-1304

$\mathrm{Pg} 8$ of 15

conditions to oxidize aliphatic compounds by reactions (1) and (2) in this temparature range ${ }^{1}$.

Two platinum group metals were studied as co-catalysts, palladium and rhodium. Palladium performed better in reducing the percentage of organic carbon released from solution as $\mathrm{CO}$. The palladium metal formed during the oxidation of $\mathrm{CO}$ is reoxidized back to $\mathrm{Pd}^{+2}$ by nitric acid.

$$
\begin{aligned}
& \mathrm{CO}+\mathrm{Pd}^{+2}+\mathrm{H}_{2} \mathrm{O} \rightarrow \mathrm{CO}_{2}+\mathrm{Pd}+2 \mathrm{H}^{+} \\
& \mathrm{Pd}+2 \mathrm{HNO}_{3} \longrightarrow \mathrm{Pd}^{+2}+\mathrm{H}_{2} \mathrm{O}+2 \mathrm{NO}_{2}^{-}
\end{aligned}
$$

Unlike palladium, rhodium formed a significant amount of $\mathrm{N}_{2} \mathrm{O}$ when used as a co-catalyst. Rhodium catalyzes the NO- oxidation of $\mathrm{CO}$ to produce $\mathrm{CO}_{2}$ and $\mathrm{N}_{2} \mathrm{O}^{7}$. Even though the extent to which palladium is aiding in oxidation of the organic materials in solution is unknown, palladium is known to be an effective catalyst for oxidation of many types of organic compounds ${ }^{8}$.

During some runs when an air sparge rate of $500 \mathrm{ml} /$ minute was used, the solution temperature had to be raised to near $150^{\circ} \mathrm{C}$ to complete the oxidation. This is probably due to the formation of hydroperoxide compounds which decompose in the $130-150^{\circ} \mathrm{C}$ range ${ }^{1}$. The extent to which the oxygen is interacting with the organic radicals is unknown. Oxygen could also enter as an oxidant by oxidizing dissolved $\mathrm{NO} \cdot \mathrm{NO}_{2}$. Even though the selfdecomposition of organic hydroperoxides have a high activation energy ${ }^{1}$, the concentration of these compounds are self limiting

$$
\mathrm{RCH}_{2} \mathrm{OOH}+\mathrm{R}^{\prime} \mathrm{CH}_{2} \mathrm{OOH} \rightarrow \mathrm{RCHO}+\mathrm{R}^{\prime} \mathrm{CHO}+2 \mathrm{H}_{2} \mathrm{O} \quad \Delta \mathrm{H} \propto-166
$$

\section{Oxidation Under Microwave Digestion Conditions}

The microwave heated oxidation/dissolution of plastics in concentrated $\mathrm{HNO}_{3}$ at atmospheric pressure is very slow. The oxidation/dissolution in concentrated phosphoric acid was found to have little effect. The nitric acid oxidation reactions at elevated pressures probably take advantage of reactions (1) and (2) by concentrating the $\mathrm{NO}_{2} \cdot$ and NO$\cdot$ by-products. The oxidation rate is third order with respect to the combination of these two gases.

Experiments conducted with 0.1 gram samples and $5 \mathrm{~mL}$ of $70 \%$ nitric acid in a $100 \mathrm{~mL}$ reaction vessel at 135 psig successfully dissolved a variety of plastics. Materials dissolved in less than 15 minutes include polyethylene, polyvinylchloride, high density polyethylene (HDPE), polypropylene, Tygon, and a styrene-divinylbenzene resin (Rohm and Haas Amberlite IRN-150). In a separate experiment, a HDPE sample was dissolved in phosphoric-0.5M nitric acid in 90 minutes.

Additional experiments studied the ability to dissolve and oxidize plastics. The results are given in Table 2. In these tests, plastics were dissolved in the microwave vessels and the liquid and gas fractions were passed through the nitric-phosphoric acid system. When this was done, the test showed that a fraction of the initial carbon appeared in the gas phase as $\mathrm{CO}$ and $\mathrm{CO}_{2}$ while the remaining carbon was dissolved in solution as compounds which oxidize at rates comparable to TBP or butanol (first order with a few hour half-life). The last experiment in 
WSRC-RP-93-1304

Pg 9 of 15

Table 2. Carbon Balance for Oxidation of High-Density Polyethylene Under Typical Microwave Digestion Conditions ( 100 watts).

\begin{tabular}{|c|c|c|c|c|c|}
\hline $\begin{array}{l}\text { Oxidizing } \\
\text { Solution }\end{array}$ & $\begin{array}{c}\text { Digestion } \\
\text { Time (min) }\end{array}$ & $\begin{array}{l}\text { \% Carbon } \\
\text { Released to } \\
\text { gas phase }\end{array}$ & $\begin{array}{r}\mathrm{Cart} \\
\mathrm{Con} \\
\% \mathrm{CO} \\
\end{array}$ & $\begin{array}{l}\text { gas } \\
\text { sition } \\
\% \mathrm{CO}_{2}\end{array}$ & $\begin{array}{c}\% \text { Oxidized } \\
\text { after } \mathrm{HNO}_{3} / \\
\mathrm{H}_{3} \mathrm{PO}_{4}\end{array}$ \\
\hline $15.9 \mathrm{M} \mathrm{HNO}_{3}$ & 30 & $10.7 \pm 2$ & 28 & 72 & 220.7 \\
\hline$"$ & 30 & $50.0 \pm 2$ & 21 & 79 & $\geq 89.2$ \\
\hline " & 40 & $81.5 \pm 2$ & 21 & 79 & - \\
\hline $\begin{array}{l}1.05 \mathrm{M} \mathrm{HNO}_{3} / \\
13.8 \mathrm{M} \mathrm{H}_{3} \mathrm{PO}_{4}\end{array}$ & 40 & $74 \pm 2$ & 18 & 82 & $\begin{array}{l}- \\
-\end{array}$ \\
\hline $\begin{array}{l}0.55 \mathrm{M} \mathrm{HNO}_{3} / \\
14.3 \mathrm{M} \mathrm{H}_{3} \mathrm{PO}_{4}\end{array}$ & 55 & $84 \pm 2$ & 14 & 86 & - \\
\hline $\begin{array}{l}0.001 \mathrm{M} \mathrm{Pd}^{2+} / \\
1.00 \mathrm{MNO}_{3} / \\
13.9 \mathrm{M} \mathrm{H}_{3} \mathrm{PO}_{4}\end{array}$ & 50 & $98 \pm 2$ & 6 & 94 & $\begin{array}{ll}- \\
-\end{array}$ \\
\hline
\end{tabular}

Table 2 shows that high-density polyethylene can be, within experimental error, quantitatively oxidized to $\mathrm{CO}_{2}$ and $\mathrm{CO}$ under typical microwave digestion conditions in relatively dilute nitric acid. Addition of $0.001 \mathrm{M}$ palladium to the oxidizing solution reduced the fraction of $\mathrm{CO}$ produced by a factor of three. Minimizing $\mathrm{CO}$ in the gas phase is important because $\mathrm{CO}$ and NO- and/or $\mathrm{NO}_{2} \cdot$ can form explosive mixtures. Higher concentrations of palladium will probably reduce the $\mathrm{CO}$ fraction even further. Realize that this is $6 \%$ of the carbon gases, the CO concentration in the vapor phase is diluted by other gases such as $\mathrm{N}_{2}$ and $\mathrm{H}_{2} \mathrm{O}$.

\section{4-L Corrosion Studies}

Tests were performed to obtain corrosion rates for 304-L stainless-steel in solutions expected to be typical of those to be processed after use in treatment of the TRU waste. The tests were performed at room temperature since it is expected the solutions will be cooled before being processed. $\mathrm{HCl}$ was included as a parameter since much of the TRU organic waste to be oxidized contains significant amounts of chlorine (PVC and neoprene). The results of the study are given in Table 3. Solutions of expected concentrations of $\mathrm{HNO}_{3}$ in concentrated $\mathrm{H}_{3} \mathrm{PO}_{4}$ 
WSRC-RP-93-1304

$\mathrm{Pg} 10$ of 15

Table 3. 304-L Corrosion in $\mathrm{HCl} / \mathrm{HNO}_{3} / \mathrm{H}_{3} \mathrm{PO}_{4}$ at $\sim 20^{\circ} \mathrm{C}$.

\begin{tabular}{cccc}
\hline$\left[\mathrm{HCl} \_\right.$ & {$\left[\mathrm{HNO}_{3} \perp\right.$} & $\mathrm{HH}_{3} \mathrm{PO}_{4} \perp$ & $\frac{\begin{array}{c}\text { Corrosion Rate } \\
(\text { mils/yr) }\end{array}}{2.1}$ \\
0.12 & 0 & 0 & 3.1 \\
1.0 & 0 & 0 & $10.0 \pm 1.2$ \\
0 & 0.1 & 14.8 & $\leq 0.36$ \\
1.0 & 0.1 & 13.5 & 224 \\
1.0 & 0 & 13.6 & 16 \\
\hline
\end{tabular}

produced non-corrosive mixtures. The combination of $\mathrm{HCL}$ and $\mathrm{HNO}_{3}$ is very corrosive. One of these two compounds would have to be eliminated before the solution could be processed. $\mathrm{HNO}_{3}$ can be quantitatively destroyed with solid oxalic acid. The $\mathrm{HCl}$ is slowly removed form the solution with air sparging at elevated temperatures $\left(\sim 150^{\circ} \mathrm{C}\right)$. Up to $1.0 \mathrm{M} \mathrm{HCl}$ in concentrated phosphoric acid is in the good range $(<20 \mathrm{mils} / \mathrm{yr})$.

\section{ENGINEERING CONSIDERATIONS}

This process is being developed to completely oxidize solid TRU-contaminated organic materials, particularly plastics. The residual TRU components can be collected and put in a safe storage form or a form acceptable for the Defense Waste Processing Facility (DWPF). Success in the effort will eliminate the reliance on shipping solid waste to the Waste Isolation Pilot Plant (WIPP) facility.

The process envisioned will be configured to handle 1.5 million pounds of a wide range of solid TRU waste of which about 825,000 is combustible. The process will oxidize the combustibles with a mixture of cellulose (14\%), rubber materials (3\%), plastics (64\%), absorbed oil $(9 \%)$, resins and sludges $(4 \%)$, and other miscellaneous organics $(6 \%)$ in the same vessel without requiring separation. Other non-combustible waste such as glass, ceramics, and metals will be present and is expected to have the majority of TRU components dissolved from its surface.

Data from microwave oxidations of HDPE (high-density polyethylene) shows a rate of $14.2 \mathrm{~g} /$ liter-hr. This translates into a throughput of $118 \mathrm{lb} / \mathrm{hr}$ for a 1000 gallon system. Atmospheric pressure oxidation of non-aliphatic organics such as EDTA, cellulose, and TBP, should oxidize an order of magnitude faster, or $1000 \mathrm{lb} / \mathrm{hr}$. 
WSRC-RP-93-1304

$\mathrm{Pg} 11$ of 15

The system is a combination of five primary unit operations: feed preparation, microwave dissolution, nitric-phosphoric acid oxidation, acid recycle, and metal precipitation/calcination.

\section{Feed Preparation}

In the feed preparation step, the solid organics will be shredded to increase their surface area and dissolution rates. Shredders and pulverizing equipment is commercially available which can handle different types of metals, concrete, and plastics.

\section{Dissolution}

From feed preparation, the solids will be placed in dissolution vessels. The dissolution will use nitric acid or a mixture of nitric acid and phosphoric acid to dissolve the organics into solution. The plastics, which represent about 675,000 pounds of the total feed, will be the slowest to dissolve. Based on this figure and a utilization factor of $20 \%$, the following is true:

Years to Completely Dissolve

1.0

4.0
Dissolution Rate (\#/hr)

395

197

132

100

Dissolution should be the rate-limiting step.

In addition to dissolution of plastics, hot concentrated phosphoric acid has been shown to dissolve plutonium oxide more efficiently than $0.05 \mathrm{M} \mathrm{HF}$ in $\mathrm{HNO}_{3}$ (the solution often used at $\mathrm{SRS}$ for dissolution of $\left.\mathrm{PuO}_{2}\right){ }^{9}$ This means that the dissolution liquid should be very effective at decontaminating the non-combustible solids fed to it. As a result, the process will be suitable for all of the waste types present in the TRU waste containers.

At this stage of reaction, oxidation may not yet be complete. However, with the plastics in solution, this liquid can be fed to the oxidation unit for complete reaction to $\mathrm{CO}$ and $\mathrm{CO}_{2}$ gases. The decontaminated non-combustible components will be separated from the liquid using either filters or centrifuges.

\section{Oxidation}

Oxidation will be performed in a mixture of phosphoric and dilute nitric acid. Although phosphoric acid acts as a dehydrating agent, its primary purpose is to raise the temperature at which nitric acid stays as a liquid from $125^{\circ} \mathrm{C}$ to $190^{\circ} \mathrm{C}$. These temperatures are needed to completely oxidize organic intermediates which do not decompose below $150^{\circ} \mathrm{C}$.

Until recently, oxidation was viewed as the rate-limiting step because dissolution was part of this step. However, with the dissolution run separate from oxidation, oxidation is expected 
to proceed at an acceptable rate. Using data acquired from the oxidation of neoprene, which is considered to be worst-case once all organics are in solution, it was determined that a 1000 gallon solution could oxidize these materials at a rate of $115 \mathrm{lbs} / \mathrm{hr}$.

\section{Acid Recycle}

Acid recycle will also be another key part of the process. As the reaction progresses, $\mathrm{NO} \cdot$ and $\mathrm{NO}_{2} \cdot$ are released from solution and nitric acid is depleted. As a result, the NO- and $\mathrm{NO}_{2} \cdot$ need to be recovered as nitric acid in order to maintain the initiation of reactions. At the same time, $\mathrm{HCl}$ gas from the oxidation of PVC must be allowed to pass through to be recovered in a subsequent step. Several different approaches are being considered with the goal being to simplify the process as much as possible. Acid recovery units are a commercially available technology.

\section{Metal Precipitation/Filtration}

The presence of TRU components, fission products, stainless steel, and lead will lead to a number of metal ions in the oxidation solution. Of particular concern is the potential for a build-up of materials to form a critical mass. Metals can be recovered by precipitation as either as phosphates or oxalatophosphates. The precipitates can then be separated using filtration ${ }^{10}$.

\section{CONCLUSIONS}

Complete oxidation of many types of organic compounds is possible in a $0.1 \mathrm{M}$ $\mathrm{HNO}_{3} / 14.8 \mathrm{M} \mathrm{H}_{3} \mathrm{PO}_{4}$ solution with air sparging. Oxidation of aliphatic compounds can be accomplished under typical microwave digestion conditions $\left(\sim 180^{\circ} \mathrm{C}\right.$ and 4 atmospheres pressure). Experimental data show that significant throughputs can be obtained for both aliphatic (12 g/liter $\cdot h r)$ and non-aliphatic materials (120 g/liter $h r)$.

Trace amounts of palladium should be capable of minimizing the production of $\mathrm{CO}$ to near $1 \%$ of the released carbon gases. This limits the hazards present due to flammable levels of $\mathrm{CO}$. Use of palladium should also minimize the production of $\mathrm{N}_{2} \mathrm{O}$ which can not easily be reoxidized to $\mathrm{HNO}_{3}$.

The released $\mathrm{HNO}_{3}, \mathrm{NO}$, and $\mathrm{NO}_{2} \cdot$ can be reoxidized in a standard air driven acid recovery system providing a cheap source of oxidant. There should be no ash produced from the process making this process more environmentally contained. There are existing resins that can be used to absorb hazardous metals such as mercury, silver, lead, and cadmium that work well in phosphate solutions ${ }^{11}$. The reaction conditions were relatively mild, making the process potentially easy and cheap to implement. Phosphoric acid, $\mathrm{H}_{3} \mathrm{PO}_{4}$, and its solutions only mildly attack common stainless-steels (such as $304-\mathrm{L}$ ), especially at room temperature ${ }^{12}$. This would make handling and containing process solutions in plumbing and tanks safe and inexpensive. 
WSRC-RP-93-1304

$\mathrm{Pg} 13$ of 15

\section{ACKNOWLEDGEMENTS}

I would like to acknowledge David T. Hobbs of SRTC/WSRC for his gas sample analysis support and James D. Clark for his technical support in performance of microwave digestion experiments.

\section{REFERENCES}

1 Seminov, N.N., Some Problems in Chemical Kinetics and Reactivity, Princeton Univ. Press, vol. 1 and 2, 1958.

2 Dickerson, R.E., Molecular Thermodynamics, the Benjamin/Cummings Publ. Co., 1969.

3 Smith, J.R., Laboratory Notebook WSRC-NB-91-81, page 42, Savannah River Site, Aiken, SC 29808.

4 Smith, J.R., Laboratory Notebook WSRC-NB-93-160, page 23, Savannah River Site, Aiken, SC 29808.

5 Smith, J.R., Air-Nitric Acid Destructive Oxidation of Organic Wastes, WSRC-MS-93-169, Savannah River Site, Aiken, SC 29808.

6 Fuson, R.C., Advanced Organic Chemistry, John Wiley and Sons, Inc., 1950, p. 507.

7 Dickson, R.S., Organometallic Chemistry of Rhodium and Iridium, Academic Press, Inc., 1983, p. 7.

8 Maitlis, P.M., The Organic Chemistry of Palladium, Academic Press, Inc., 1971.

9 Katz, J.J., Seaborg, G.T., and Morss, L.R. (editors), The Chemistry of the Actinide Elements, Chapman and Hall, 1986, pp. 700-701.

10 Cleveland, J.M., The Chemistry of Plutonium, American Nuclear Society, 1979, p 438.

11 Osteen, A.B. and Bibler, J.P., Treatment of Radioactive Laboratory Waste for Mercury Removal, Water, Air, and Soil Pollution, 56, 63-74 (1991).

12 Schweitzer, P.A. (editor), Corrosion Resistance Tables, 3rd Edition, Marcel Dekker, Inc., 1991. 


\section{Figures}

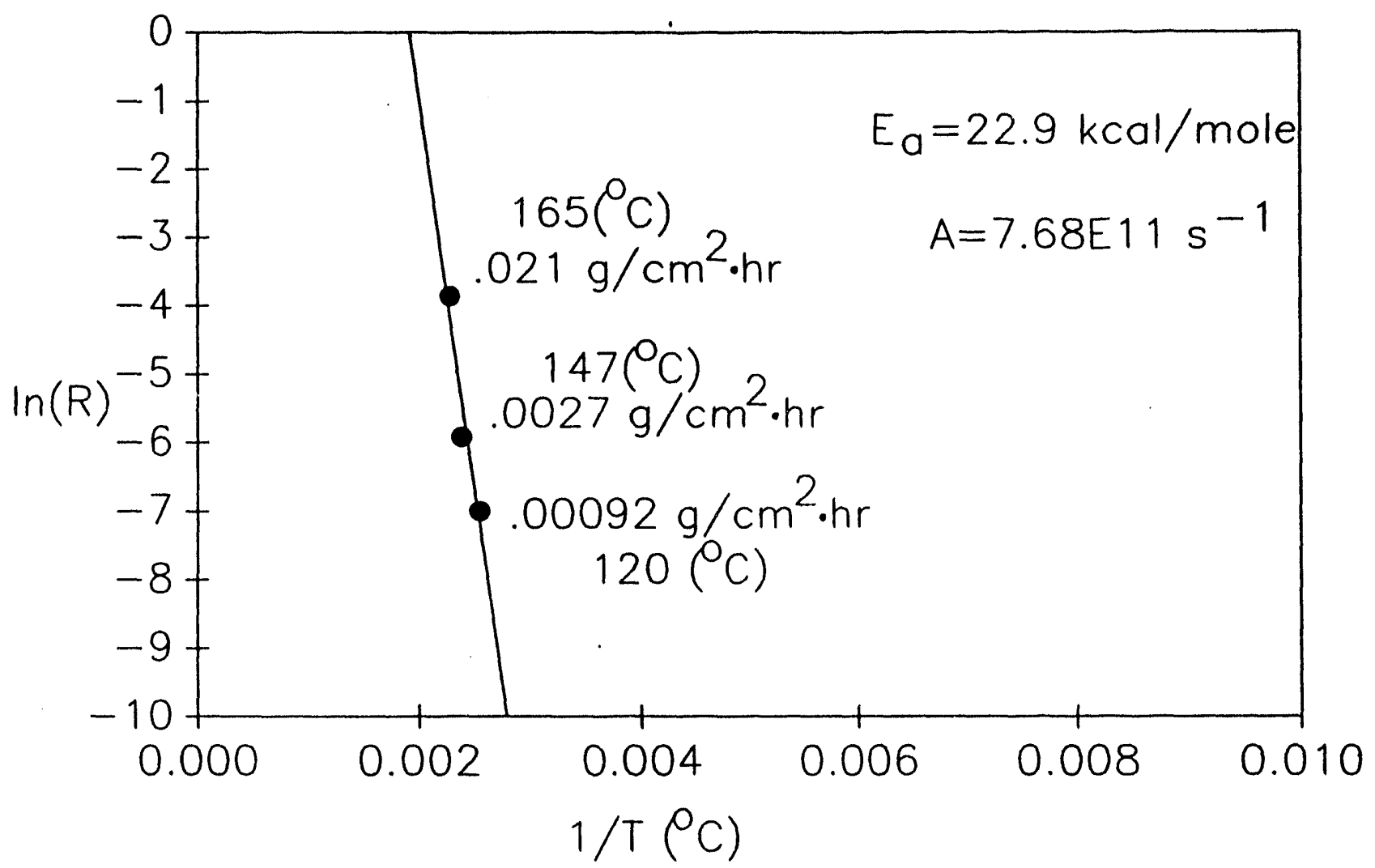

Figure 1. Oxidation Rate, $\mathrm{R}$, for Neoprene in $0.1 \mathrm{M} \mathrm{HNO} / 14.8 \mathrm{M} \mathrm{H} \mathrm{H}_{3} \mathrm{PO}_{4}$ Solution at Varyung Temperature. 
Distribution:

A.L. Blancett, 773-A

J.R. Knight, 773-A

F.R. Graham, 773-A

W.E. Stevens, 773-43A

A.F. Riechman, 773-A

M.G. Looper, 676-1T

S.D. Fink, 773-A

M.C. Thompson, 773-A

H.E. Hootman, 773-41A

J.A. D'Amelio, 705-3C

W.F. Swift,705-3C

R.H. Hsu, 773-43A

P.J. Rowan, 232-H

J.R. Dollar, 232-H

G.B. Woolsey, $992 \mathrm{~W}-1$

M.L. Meyer,676-1T

J.R. Smith, 773-A

R.A. Pierce, 773-A

E.F. Sturcken, 773-A

SRTC Records(4)

CTS/SRTC Records 

